\title{
EFEKTIFITAS PENGGUNAAN APLIKASI BERBASIS ANDROID SEBAGAI DAMPAK DARI PENYEBARAN COVID-19
}

\author{
NATALIA TRI ASTUTI', AGUS WILSON ${ }^{2}$ \\ 1Program Studi Informatika, Teknik Informatika, Universitas Indraprasta PGRI \\ Email: Natnatalia.lia@gmail.com \\ 2Program Studi Informatika, Teknik Informatika, Universitas Indraprasta PGRI \\ Email: wilsonaw2580@gmail.com
}

\begin{abstract}
Abstrak
Latar belakang penelitian ini adalah pembelajaran jarak jauh yang memanfaatkan media berupa aplikasi berbasis android sehubungan dengan pandemik global covid-19 yang dialami oleh berbagai negara, salah satunya Indonesia. Kondisi ini mempengaruhi pergerakan berbagai macam sektor, termasuk sektor pendidikan. Setelah melewati beberapa bulan dengan kondisi pandemi global ini, dengan seluruh kegiatan belajar-mengajar dari berbagai jenjang dilakukan dari rumah, maka penggunaan metode yang tepat pun menjadi perhatian yang sangat serius. Belajar dari rumah merupakan salah satu cara yang diharapkan mampu menekan penyebaran covid-19. Banyak media pembelajaran jarak jauh yang tersedia, maka perlu diketahui efektifitas dari penggunaan media tersebut untuk digunakan dalam pembelajaran jarak jauh. Metode yang digunakan dalam penelitian ini adalah kualitatifkuantitatif dengan sampel 30 mahasiswa yang dipilih secara acak dengan catatan mahasiswa tersebut "melek teknologi". Metode pengumpulan data dilakukan melalui kuesioner dengan memanfaatkan media elektronik dan jaringan internet. Hasil penelitian ini menunjukkan tidak semua aplikasi berbasis android dapat digunakan dengan efektif dalam pembelajaran jarak jauh. Penelitian ini diharapkan dapat memberi pandangan dan referensi baru tentang efektifitas penggunaan media elektronik dalam belajar, sehingga dapat meningkatkan efektifitas pembelajaran jarak jauh untuk berbagai jenjang pendidikan.
\end{abstract}

Kata Kunci: pembelajaran jarak jauh, media elektronik, android, covid-19

\begin{abstract}
The background of this research is distance learning which utilizes media in the form of android-based applications in connection with the global covid-19 pandemic experienced by various countries, one of which is Indonesia. This condition affects the movement of various sectors, including the education sector. After going through several months with this global pandemic condition, with all teaching-learning activities from various levels carried out from home, the use of appropriate methods is a very serious concern. Learning from home is one way that is expected to be able to suppress the spread of covid-19. Many distance learning media are available, so it is necessary to know the effectiveness of using these media to be used in distance learning. The method used in this research was qualitative-quantitative with a sample of 30 students chosen at random with the student record "technology literate". The data collection method was carried out through a questionnaire using electronic media and internet networks. The results of this research indicate that not all android-based applications can be used effectively in distance learning. This research is expected to provide new views and references on the effectiveness of the use of electronic media in learning, so as to increase the effectiveness of distance learning for various levels of education.
\end{abstract}

Keywords: distance learning, electronic media, covid-19 


\section{PENDAHULUAN}

Belajar merupakan sebuah proses yang tidak pernah berhenti dalam setiap kehidupan manusia. Tanpa kita sadari, proses belajar dalam hidup berlangsung terus menerus. Proses belajar tidak selalu dilakukan di sekolah atau tempat berlabel pendidikan lainnya, akan tetapi di manapun dan kapanpun kita berada, proses belajar dapat terus berlangsung.

Beberapa bulan terakhir dunia dan termasuk Indonesia sedang dikhawatirkan dengan adanya penyebaran covid-19 atau lebih dikenal luas dengan nama virus corona. Covid-19 merupakan nama yang dinyatakan secara resmi oleh organisasi kesehatan dunia (WHO) pada bulan Februari 2020. Ghebreyesus menyebut, $\mathrm{C}-\mathrm{o}=$ corona, $\mathrm{v}-\mathrm{i}=$ virus, dan $\mathrm{D}=$ disease. Jadi Covid bisa diartikan penyakit virus corona, angka 19 menandai tahun pertama kali virus teridentifikasi (Utomo, 2020). Ancaman virus corona yang konon berasal dari provinsi Hubei, China yang kini berstatus sebagai pandemic sangat mengkhawatirkan seluruh kalangan masyarakat. Menyikapi hal tersebut, pemerintah Indonesia menerapkan social distancing. Penerapan social distancing berdampak pada kegiatan belajar mengajar di berbagai jenjang pendidikan, termasuk perguruan tinggi. Pemerintah Indonesia melalui Menteri Pendidikan Nadiem Makarim memutuskan untuk menerapkan Pembelajaran Jarak Jauh (PJJ). Penerapan ini diputuskan secara mendadak mengingat situasi yang tidak memungkinkan untuk pembelajaran dilakukan secara tatap muka seperti biasanya. Hal ini dilakukan sebagai usaha untuk memutus rantai penyebaran covid-19 yang semakin hari semakin meluas di seluruh dunia, termasuk Indonesia.

Dalam keadaan pandemi seperti ini seakan-akan 'memaksa' dunia pendidikan untuk beradaptasi melakukan perubahan pembelajaran melalui daring (online). Peran media internet menjadi pilihan kebutuhan dominan dalam dunia pendidikan saat ini, bahkan diperkirakan akan semakin populer di masa mendatang. Internet memudahkan penggunanya dalam mengirim dan menerima segala bentuk informasi, baik berupa gambar, suara, teks, maupun video. Dengan telah disematkannya sebuah mesin pencari pada Google, maka dapat dengan mudahnya kita mencari suatu informasi di internet (Zaenal, 2011). Pemanfaatan teknologi informasi (IT) kini semakin meluas, seperti halnya di dunia bisnis sering kita mendengar e-business atau ecommerce, dalam dunia pemerintahan menggunakan istilah e-government, sedangkan dalam dunia pendidikan dikenal dengan nama e-learning (Edy, 2011). E-learning adalah pembelajaran menggunakan perangkat elektronik yang dilakukan secara daring (online). Salah satu dari contoh model E-learning ialah belajar dengan memanfaatkan Google Classroom. Google Classroom merupakan salah satu media pembelajaran elektronik jarak jauh yang digunakan untuk memenuhi kebutuhan belajar para pelajar dari berbagai jenjang pendidikan termasuk perguruan tinggi. Beberapa aplikasi pembelajaran lainnya seperti Zoom Meeting, Google Meet, Google Classroom, Edmodo, Quizizz, WhatsApp Group, maupun Webex sudah tersebar luas dan dapat dengan mudah mengunduhnya pada perangkat telepon seluler berbasis android. Internet dengan segala kelebihan dan kekurangannya telah menjelma menjadi kebutuhan mutlak yang harus dimanfaatkan dan dimiliki oleh guru/dosen dan mahasiswa. Ini tentu bukanlah hal yang mudah, mengingat cukup banyaknya problematika dalam dunia pendidikan di Indonesia, seperti seringnya perubahan kurikulum seiring bergantinya menteri terpilih, capaian kualitas pembelajaran yang diinginkan masih belum merata, kurangnya kompetensi keilmuan guru/dosen, rendahnya kesiapan mahasiswa belajar mandiri, serta keterbatasan jangkauan internet di beberapa wilayah di Indonesia.

Bagi guru/dosen dituntut untuk lebih selektif dan kreatif memilih metode dan media apa yang cocok dalam menyampaikan materi secara daring, karena pemilihan penggunaan media yang tepat akan menentukan berhasil tidaknya pembelajaran. Hal ini perlu agar mahasiswa tidak cepat merasa bosan saat menerima materi dan mengerjakan tugas yang diberikan baik kegiatan menulis maupun motorik.

Berdasarkan masalah yang telah dikemukakan diatas, penulis mencoba menganalisa beberapa aplikasi e-learning yang sering digunakan untuk mengetahui efektifitasnya terhadap pembelajaran dilingkungan perguruan tinggi (kalangan mahasiswa). Jadi, tujuan pembelajaran 
tetap tercapai sehingga pendidikan sebagai wadah membentuk karakter manusia yang lebih baik tetap terjaga (Nasri, 2018).

\section{METODE PENELITIAN}

Penelitian ini dilaksanakan di salah satu universitas swasta di Jakarta, pada tahun ajaran genap 2019/2020. Metode yang digunakan adalah metode kualitatif-kuantitatif dengan sampel 30 mahasiswa yang dipilih secara acak dengan catatan mahasiswa tersebut "melek teknologi". Metode kualitatif merupakan prosedur penelitian yang digunakan untuk menginvestigasi dan memahami fenomena apa, mengapa dan bagaimana sesuatu bisa terjadi dalam kehidupan nyata (Finlay \& Ballinger, 2006). Metode kualitatif bertujuan membentuk fakta yang mudah dipahami dan jika memungkinkan mendapatkan hipotesa baru (Finlay \& Ballinger, 2006). Metode kuantitatif digunakan untuk meneliti populasi atau sampel yang dipilih secara random untuk menganalisa data secara sistematis, terencana dan terstruktur sehingga menghasilkan hasil penelitian yang tidak menyimpang dari fakta sebenarnya (Yusuf, 2016).Teknik pengumpulan data yang digunakan adalah melalui studi kepustakaan, pengumpulan data melalui kuesioner dengan menggunakan Google Form, juga dengan menelaah dan membandingkan data dari berbagai artikel ilmiah. Data tersebut kemudian diolah dengan perhitungan persentase sederhana untuk mengetahui respon dari tiap-tiap responden. Adapun pertanyaan yang terdapat dalam kuesioner telah diuji validasnya.

\section{HASIL DAN PEMBAHASAN}

\section{a. Aplikasi Pembelajaran Berbasis Android}

Beberapa aplikasi pembelajaran berbasis android yang sangat sering digunakan akhirakhir ini dalam sistem pembelajaran jarak jauh terangkum sebagai berikut:

1. Zoom Meeting, merupakan aplikasi pertemuan online yang memungkinkan 100 penggunanya melakukan obrolan video.

2. Google Meet, aplikasi dari Google ini secara default memungkinkan 30 penggunanya melakukan panggilan video. Di samping memiliki tampilan Interface yang unik, aplikasi ini juga efisien dan mudah guna (user friendly).

3. Google Classroom, adalah aplikasi yang dirancang oleh Google dalam memudahkan tenaga pendidik dalam memberikan materi, tugas dan soal tanpa menggunakan kertas.

4. Edmodo, melalui aplikasi ini dosen dapat dengan mudah berbagi catatan, tugas, kuis maupun soal dan penilaian kepada mahasiswa hingga diskusi secara online dapat dilakukan.

5. Quizizz, aplikasi yang dirancang untuk permainan kuis interaktif dengan 4 pilihan jawaban benar-salah yang dapat digunakan dalam pembelajaran.

6. WhatsApp Group, merupakan media sosial yang banyak digunakan oleh mayoritas pengguna handphone android untuk saling berkomunikasi dan berdiskusi melalui chat, audio maupun panggilan video (maksimal 8 pengguna sekaligus) tanpa perlu biaya yang cukup mahal saat menggunakannya.

7. Webex, yaitu media tatap muka virtual dengan teknologi kolaborasi melalui video. Di mana guru/dosen dapat berinteraksi dengan mahasiswa saat memberikan materi melalui papan tulis digital melalui layar laptop/handphone yang diterapkan oleh aplikasi ini.

\section{Media Pendukung Pelaksanaan Kegiatan Belajar-Mengajar}

Pada prakteknya, media pendukung dalam pembelajaran yang dilaksanakan secara jarak jauh adalah perangkat elektronik berupa laptop/PC, smartphone berbasis android atau sejenisnya, surat elektronik, jaringan internet dan lain sebagainya. Media tersebut diperlukan untuk memaksimalkan penggunaan aplikasi berbasis android tersebut. Konsumsi internet yang diperlukan misalnya, jaringan internet yang diperlukan untuk mengoperasikan penggunaan 
sebuah aplikasi belajar sangatlah besar. Karena, dalam penggunaannya aplikasi tersebut membutuhkan jaringan internet saat dibuka (tidak hanya saat diunduh saja).

Oleh sebab itu, dalam pelaksanaannya seringkali terjadi hal di luar dugaan, seperti jaringan internet yang tiba-tiba terputus karena kuota yang terbatas atau habis, jaringan internet yang buruk karena cuaca dan lokasi yang kurang mendukung dan lain sebagainya. Kendalakendala tersebut merupakan salah satu hal yang dapat dikatakan sebagai hambatan dalam sistem belajar jarak jauh, akan tetapi sangat perlu untuk dimaklumi. Selain ketersediaan jaringan internet, kapasitas atau spesifikasi perangkat elektronik yang digunakan juga merupakan hal yang cukup penting. Semakin tinggi spesifikasi perangkat elektronik yang digunakan, maka semakin cepat pengoperasian perangkat tersebut ketika digunakan untuk belajar. Hal ini mengingat besarnya kapasitas dari aplikasi pembelajaran berbasis android, sehingga seringkali membuat lambat kinerja dari perangkat elektronik.

\section{Efektifitas Penggunaan Aplikasi Android Untuk Pembelajaran Jarak Jauh}

Berdasarkan kuesioner yang diberikan kepada 30 responden, maka hasil yang didapat adalah sebagai berikut:

1. Responden yang pernah mengunduh aplikasi belajar jarak jauh dalam perangkat elektronik (mobile /gadget) mereka sebanyak 100\%;

2. Responden yang mengalami kesulitan dalam menggunakan/mengoperasikan aplikasi belajar tersebut sebanyak $42 \%$, sementara $58 \%$ lainnya merasa mudah dalam menggunakan aplikasi tersebut;

3. Responden yang mengalami kesulitan dalam proses mengunduh dan mengunggah materi pelajaran maupun tugas-tugas yang diberikan sebanyak $15 \%$ dengan $85 \%$ lainnya;

4. Responden yang merasa kesulitan memahami materi pembelajaran melalui aplikasi sebanyak $56 \%$ dan $44 \%$ lainnya merasa mudah memahami materi yang diberikan;

5. Responden yang merasa kesulitan berinteraksi dengan pengajar dan teman-teman mereka sebanyak $87 \%$, sementara $13 \%$ lainnya merasa mudah dalam berinteraksi;

6. Responden yang merasa kesulitan dalam mempraktekkan pembelajaran sebanyak $88 \%$, sementara $12 \%$ lainnya merasa tidak memiliki kendala saat harus praktek melalui media online.

7. Responden yang mengalami kesulitan/gangguan jaringan saat pembelajaran berlangsung sebanyak $43 \%$, sementara $57 \%$ diantaranya tidak merasakan hal tersebut;

8. Responden yang merasa keberatan dengan beban kuota yang digunakan untuk pembelajaran melalui aplikasi online sebanyak $56 \%$, sementara $44 \%$ lainnya sama sekali tidak keberatan.

9. Responden yang merasa terganggu dengan situasi belajar dirumah sebanyak $33 \%$, dan $67 \%$ lainnya merasa nyaman belajar dari rumah.

10. Responden yang merasa takut dan kesulitan mengikuti ujian/kuis atau tugas lain melalui aplikasi online yang menggunakan waktu terbatas sebanyak $70 \%$, sementara sisanya $30 \%$ merasa tertantang dan semangat dalam mengikuti ujian/kuis dengan pembatasan waktu yang dapat diatur dalam beberapa aplikasi online.

\section{Penelitian Sebelumnya}

Penulis mengambil beberapa hasil penelitian terdahulu untuk dijadikan rujukan studi pustaka yang dapat diuraikan sebagai berikut:

1. Hal terbesar yang menjadi kendala dalam penerapan Pembelajaran Jarak Jauh (PJJ) adalah keterbatasan jaringan internet, belum siapnya orang tua murid sebagai role model dalam pendampingan anak, serta faktor ekonomi (Atsani, 2020).

2. E-learning dapat meningkatkan mutu belajar siswa, namun dibutuhkan dukungan lembaga pemerintah dalam hal pelatihan, ketersediaan koneksi internet maupun kebijakan dalam pemanfaatan e-learning (Suharyanto \& Mailangkay, 2018). 
3. Beberapa aplikasi e-learning yang umum digunakan seperti Edmodo, Moodle, dan Google Classroom dengan beberapa kelebihan dan kekurangannya. Dibutuhkan akses internet yang stabil di seluruh wilayah Indonesia. Keterampilan para mahasiswa dan dosen pun harus lebih ditingkatkan, sehingga mampu secara maksimal memanfaatkan fitur-fitur pada e-learning (Nadziroh, 2017).

4. Penggunaan e-learning secara umum sudah efektif. Faktor kesiapan SDM dalam pelaksanaan pembelajaran perlu terus ditingkatkan, terlebih dalam hal penyediaan software dalam meningkatkan media pembelajaran sesuai dengan kebutuhan. Di samping bermanfaat dalam hal pembelajaran, e-learning dapat dijadikan sebagai bahan media promosi sekolah di publik (Hanum, 2013).

5. Pendidik harus memiliki tiga (3) kompetensi dasar dalam pembelajaran e-learning, yaitu (1) Kemampuan membuat instructional design, (2) Menguasai teknologi berbasis internet, dan (3) Menguasai materi bahan ajar yang berkualitas (Hartanto, 2016).

6. Meski dari beberapa uji karakteristik sebuah e-learning dirasa sudah berada di kondisi cukup baik, namun masih perlu dukungan dalam bentuk instruksi dan kebijakan dari lembaga penyelenggara pendidikan, dalam hal ini pihak kampus (Agustina, 2013).

7. Di lingkungan sosial, banyak masyarakat yang saat pandemi seperti saat ini membutuhkan aplikasi video konferensi yang mudah digunakan seperti Google Meet untuk mendukung kegiatan work from home (WFH) (Agustina, 2013).

8. Kesiapan pendidik dan peserta didik masih menjadi kunci keberhasilan pelaksanaan pembelajaran jarak jauh (distance learning) (Putra \& Bangunan, 2020).

\section{KESIMPULAN}

Berdasarkan penelitian yang telah dilakukan, dapat disimpulkan bahwa pembelajaran secara jarak jauh dengan menggunakan aplikasi berbasis android dirasa kurang efektif. Hal ini disebabkan oleh berbagai macam faktor. Salah satu faktor yang hampir tidak mungkin dihindari dan disalahkan adalah buruknya konektifitas atau jaringan internet. Ketika seorang mahasiswa berada diwilayah dengan jaringan internet yang sulit dijangkau, sudah pasti mahasiswa tersebut kesulitan mengakses aplikasi pembelajaran yang digunakan. Selain itu, setiap aplikasi juga memiliki kelebihan dan kekurangannya masing-masing, kelemahan dari aplikasi yang digunakan juga menjadi faktor kurang efektifnya pembelajaran secara jarak jauh, misalnya penggunaan aplikasi Edmodo, Google Classroom, WhatsApp Group dan aplikasi sejenis lainnya, yang tidak memungkinkan setiap mahasiswa dan dosen bertatap langsung walaupun melalui kamera laptop/PC/handphone. Keterbatasan tersebut sangat mungkin membuat mahasiswa tidak mengikuti kelas/pembelajaran dengan baik dan maksimal, karena guru/dosen tidak dapat melihat atau mengontrol setiap mahasiswa memperhatikan atau tidak. Sementara itu, penggunaan aplikasi dengan tatap muka melalui kamera seperti Google Meet, Zoom dan aplikasi serupa lainnya juga, memiliki kelemahan, diantaranya jika jumlah peserta cukup banyak, maka dapat berpengaruh pada jaringan, sehingga suara yang dihasilkan tidak jernih atau putus-putus. Selain itu, jika setiap peserta menyalakan microphone, maka sangat mungkin gangguan suara juga datang dari berbagai sumber sehingga menghasilkan kebisingan. Sementara jika peserta mematikan microphone, maka aktifitas belajar-mengajar menjadi kurang "hidup" karena tidak memiliki interaksi yang cukup. Akan tetapi, jika guru/dosen cukup rajin dan kreatif mengombinasikan penggunaan aplikasi tersebut secara bergantian maka pembelajaran jarak jauh ini dapat lebih maksimal dan efektif.

Kurang efektifnya penggunaan aplikasi berbasis android ini, juga dapat disebabkan oleh kurang siapnya guru/dosen dan mahasiswa dalam sistem pembelajaran jarak jauh. Karena secara mendadak, kebijakan ini harus segera diampil sehingga baik guru/dosen maupun mahasiswa tidak punya waktu yang cukup untuk mempersiapkan diri atau mempelajari penggunaan teknologi ini secara maksimal.

Peningkatan kompetensi, inovasi dan semangat para guru/dosen sangat diperlukan dalam menjalankan sistem pembelajaran jarak jauh ini, mengingat mahasiswa yang dihadapi merupakan generasi milenial dengan kemampuan teknologi yang sangat tinggi. Sementara itu, 
mahasiswa juga diharapkan mampu beradaptasi dan mempersiapkan diri untuk belajar dengan sistem pembelajaran jarak jauh, sehingga tercipta suasana belajar yang tetap nyaman, menyenangkan, efektif dan berdampak bagi kemajuan pengetahuan dan Pendidikan di masa kini dan nanti.

\section{DAFTAR PUSTAKA}

Agustina, M. (2013). Pemanfaatan E-Learning Sebagai Media Pembelajaran. Seminar Nasional Aplikasi Teknologi Informasi (SNATI), 1(1).

Atsani, K. H. L. G. M. Z. (2020). Transformasi Media Pembelajaran Pada Masa Pandemi COVID-19. Al-Hikmah: Jurnal Studi Islam, 1(1), 82-93.

Edy, I. C. (2011). Studi Pemanfaatan Web Site E-Learning dan Pengaruhnya Terhadap Motivasi. Kinerja Dan Basil Belajar Pada Guru Dan Sisa SMK Di Provinsi Jawa Tengah.

Finlay, L., \& Ballinger, C. (2006). Qualitative research for allied health professionals: Challenging choices. John Wiley \& Sons.

Hanum, N. S. (2013). Keefektifan E-learning Sebagai Media Pembelajaran (Studi Evaluasi Model Pembelajaran E-learning SMK Telkom Sandhy Putra Purwokerto). Jurnal Pendidikan Vokasi, 3(1).

Hartanto, W. (2016). Penggunaan E-Learning Sebagai Media Pembelajaran. Jurnal Pendidikan Ekonomi: Jurnal IImiah IImu Pendidikan, IImu Ekonomi Dan IImu Sosial, 10(1).

Nadziroh, F. (2017). Analisa Efektifitas Sistem Pembelajaran Berbasis E-Learning. Jurnal Ilmu Komputer Dan Desain Komunikasi Visual, 2(1), 1-14.

Nasri, U. (2018). Bersahabat dengan Ilmu: Sebuah Pengantar Filsafat IImu. Mataram: CV. Haramain Lombok.

Putra, R. A. M., \& Bangunan, P. V. K. (2020). Kendala Pelaksanaan Pembelajaran Jarak Jauh (PJJ) dalam Masa Pandemi.

Suharyanto, S., \& Mailangkay, A. B. L. (2018). Penerapan E-learning Sebagai Alat Bantu Mengajar Dalam Dunia Pendidikan. Jurnal IImiah Widya, 4(3).

Safitri,I. (2019). The Effectiveness Of Android Application As A Student Aid Tool In Understanding Physics Project Assignments. Jurnal Pendidikan IPA Indonesia. JPII 8 (4) (2019) 512-520.

DOI: 10.15294/jpii.v8i4.19433

Utomo, A. P. (2020). WHO Umumkan Nama Resmi untuk Virus Corona: Covid-19. 11 Februari.

Yusuf, A. M. (2016). Metode Penelitian Kuantitatif, Kualitatif \& Penelitian Gabungan. Prenada Media. 